\title{
Development of Pedagogical Competency Models for Elementary School Teachers: Pedagogical Knowledge, Reflective Ability, Emotional Intelligence and Instructional Communication Pattern
}

\author{
Ratnawati Susanto $^{1}$, Yuli Asmi Rozali ${ }^{2, *}$, Noni Agustina ${ }^{1}$ \\ ${ }^{1}$ Faculty of Teacher Training and Education, Universitas Esa Unggul, Indonesia \\ ${ }^{2}$ Faculty of Psychology, Universitas Esa Unggul, Indonesia
}

Received July 26, 2019; Revised September 4, 2019; Accepted September 20, 2019

Copyright $(2019$ by authors, all rights reserved. Authors agree that this article remains permanently open access under the terms of the Creative Commons Attribution License 4.0 International License

\begin{abstract}
Pedagogical competence of elementary school teachers in DKI Jakarta province is at medium level. Moreover, they have the lowest ability in recognizing their learners deeply. Apprehensively, Indonesia ranks the highest in violence case at school, which is $84 \%$ with comparison 7 out of 10 learners (Indonesian Child Protection Commission (KPAI) under the International survey of Center for Research on Women (ICRW). In addition, $39.6 \%$ of child violence is undertaken by teachers The phenomena entail the new concept of the pedagogical competence development model, which is rooted in pedagogical knowledge, reflective ability, emotional intelligence, and instructional communication pattern. The questionnaire was administered to 264 elementary school teachers in West Jakarta by employing Structural Equation Modeling (SEM) model. The results showed that the pedagogical competence model could be developed based on pedagogical knowledge, reflective ability, emotional intelligence and instructional communication patterns.
\end{abstract}

Keywords Pedagogical Competence, Pedagogical Knowledge, Reflective Abilities, Emotional Intelligence, Instructional Unidirectional Patterns

\section{Introduction}

The core of learning lies in the ability of interaction and a fundamental teachers' understanding to students in order to facilitate the learners' potential and self-actualization. Pedagogical competence is the basis of teachers' preparation in their community and formative ethics (1) The preparation of the pedagogical competence of in-service and pre-service teacher has not been conducted well (2). Pedagogical competencies that are optimally integrated with the role and functions become the best in instruction process and the quality of education (3). Results describe the contribution of pedagogical competencies to learning outcomes $94.50 \%$ (4) and performance of primary school teachers $46.7 \%$ (5).

The preparation of teachers referring to the development of pedagogical competence model emphasizes the concern of teachers and learners ' relationship in cultural aspects and becomes an authentic and responsive maintenance action for the transformation of the students ' behavior (6). Pedagogy evolves as tools and scientific methods that bridge the achievement gap and intrinsic quality as a result of social and economic inequality and improve the personal quality and learning achievement (7). Thus, the mastery and understanding of the situation and condition of the learners' environment is a commitment to design the challenge into learning management opportunity in the classroom (8).

This research is crucial conducted because of some consideration (a) focus on continuous professional development based on regulation of Ministry of Administrative and Bureaucratic Reform (PERMENPAN-RB) number 16 year 2009 to overcome the low professionalism teachers represented in data of Human Resources Agency of Culture Education and The Improvement of Education Quality of Ministry of Education and Culture that 51\% (2.92 million teachers) has not been qualified in pedagogical and professional competence; (b) $29.5 \%$ (862) has not met the teacher certification (9); (c) the result of Clara Ika Sari Budhayanti's finding (2012) showed that pedagogical competence of elementary school teachers in DKI Jakarta was at medium category (average score was 189.44 and standard deviation was 21.976, highest score was 246, lowest score was 118,128 with lowest aspect is ability to know the learners $30.43 \%$ ) (10); (d) low quality of 
learning process $(11)$ low performance $(12,13)$ with the period of 5-38 years graduated from the higher education and taught without following the science and communication development (14) the violence of children in schools in various areas in Indonesia is at the highest level in which $84 \%$ learners faced it with the comparison of 7 out of 10 students (Indonesia Child Protection Commission based on the international Center for Research on Women/ICRW survey) (16); 39.6\% the violence carried out by teachers (www.kompas.com) (17) the violence increases dramatically and it is horrible because the culprit is teacher or school officer (18). Those phenomena support the new concept of pedagogical competence development model based on pedagogical knowledge, reflective ability, emotional intelligence and instructional communication pattern.

\section{Literature Review and Research Methodology}

\subsection{Materials}

\subsubsection{Pedagogical Knowledge}

Knowledge is everything that is known and is a fundamental level of the way human thinking (19). Pedagogical knowledge must be mastered by teachers for guiding and managing learning interactions in the classroom (20) Law No. 14 year 2005 on teacher and lecturer formulates that pedagogical knowledge includes understanding the concept of (a) educational philosophy, (b) psychology of child development, (c) learning theory.

\subsubsection{Reflective Ability}

Reflective ability is associated with intellectual abilities and manifested as mental activity of thinking, reasoning, solving problems to reflective ability (20). Reflective attitude habituation begins with a willingness to listen sincerely and to experience (21) Regulation No. 16 year 2007 on standards of academic qualification and teacher competence states that reflective capability supported by pedagogical knowledge will provide the teacher's understanding of the students and lead to effective action as pedagogical competence.

\subsubsection{Emotional Intelligence}

Teacher emotions contribute to the attitude and readiness to support or refuse in understanding and accepting students and be the initial stage to keep the relationships (22). The process of learning interactions is very dominant with the role of teachers as learning communicators associated with emotion characteristics. Teachers who have uncontrollable emotions cannot control his or her intellectual attitude and intellect. The Emotional intelligence is seen from the ability of (a) recognizing self-emotion, (b) managing emotions, (c) motivating oneself, (d) recognizing the others' emotions and (e) establishing relationships (23) the more emotional savvy, the earlier to detect and manage her/ his emotion and others' emotion constructively and effectively in undertaking her/ his function and roles (24).

\subsubsection{Instructional Communication Pattern}

Communication is an integrated activity in life. In education is called instructional communication in which it is patterned and designed specifically to change target behavior in a better direction (25). Contextualize undegradable conversation involves the psychological atmosphere between teachers and learners and build the instructional communication constructions to determine behavioral changes (26). Interactive educative communication is a part of pedagogical competence: (a) The dialogue among individuals to discover the idea (b) Humanism and cognitive patterns.(27), (c) Communication pattern with politeness strategy (27), (d) situation used in instructional communications is situated learning (28), (e) Emphasis on student and teacher-centered approach, (f) Interactive communication pattern by generating students ' interest to build innovation and competitiveness (29) (30), (g) A reciprocal stimulus and response between teachers and students with the function of designer, communicator and communicant (31). The embodiment of educative instructional communication pattern: (a) psychological freedom, (b) opportunities reveal difficulties, weaknesses, strengths, (c) mentoring and guidance of achievement of learning objectives, (d) the communication of reciprocal instructional ideas (32), (e) Means of communication patterns of educative ideas on the domain of knowledge, skills and attitudes (33), (f) Implementation of group communication patterns-group, individual, informative, instructional and persuasive (35).

\subsubsection{Pedagogical Competence}

The Law of the Republic of Indonesia No. 20 year 2003 on national education system describes that pedagogical competence includes mastering some aspects as follows: (a) the characteristics of learners, (b) learning theories and principles of learning, (c) curriculum development, (d) learning activities, (e) learners ' potential development, (f) communication with learners, and (g) assessments and evaluations. When a teacher has pedagogical competence, it is manifested in learning interaction. Students who are concerned, served, valued, listened to, reinforced by giving positive words, guided, experienced learning can develop their potential. The violence will not come up if the application of pedagogical competence is conducted in learning interaction (36).

The implementation of educating the learners emerges in profile of pedagogical competence (37) and teacher's action (38) (a) identifying the learning characteristics of a student, (b) ensuring a student's opportunity to participate actively, (c) organizing the class for different characteristics, (d) knowing the cause of the learning behaviour deviations, (e) develop potential and deficiencies, and (f) humanistic actions. 


\subsection{Research Methodology}

2.2.1. Research Design

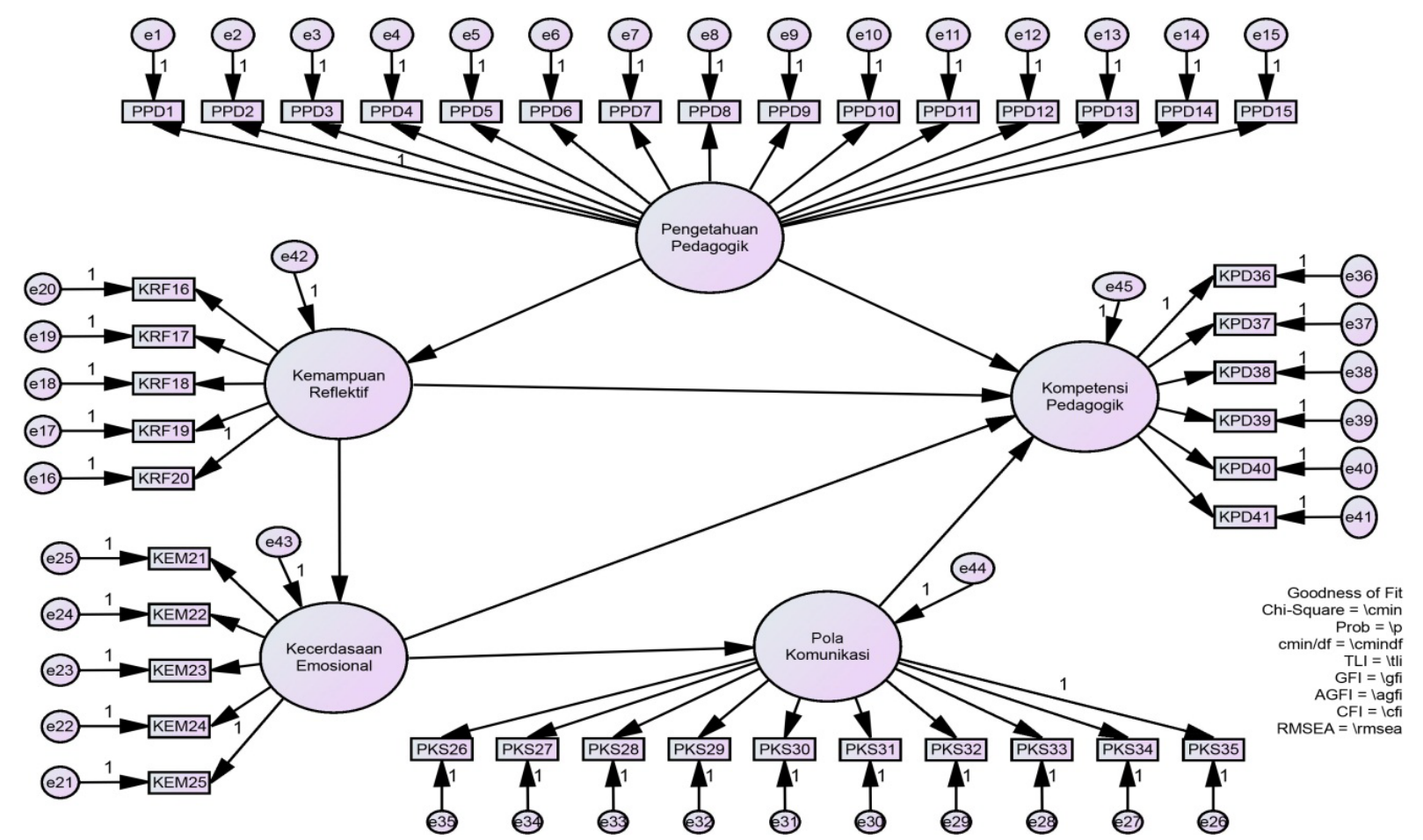

Figure 1. Design Research Description

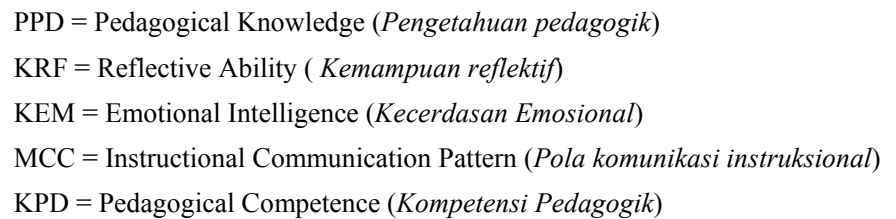

\subsubsection{Data Collection Techniques}

The technique of data collection used a questionnaire administered to 264 elementary school teachers in West Jakarta. The research was conducted for 6 months.

\subsubsection{Data Analysis Techniques}

Data analysis of the dominant factor of pedagogical competence profile was carried out by identifying the models, assessing the criteria of Goodness-of-Fit, staging the modeling and analysis of structural equations, analyzing the first and second-order measurement models of CFA and SEM.

\section{Results}

\subsection{Construct Validity}

The construct validity test indicated the size of the indicator reflecting the latent construction of the theory through the Confirmatory Factor Analysis (CFA) with the following table. 
Table 1. Construct Validity

\begin{tabular}{|c|c|c|c|}
\hline & Estrmate \\
\hline PPD11 & $<$ & Pedagogic knowledge & .760 \\
\hline PPD12 & $<\ldots$ & Pedagogic knowledge & .716 \\
\hline PPD13 & $<. .$. & Pedagogic knowledge & .761 \\
\hline PPD14 & <... & Pedagogic knowledge & .758 \\
\hline PPD15 & $<$ & Pedagogic knowledge & .726 \\
\hline KRF20 & «... & Reflective Ability & .776 \\
\hline KRF19 & $<. .$. & Reflective Ability & .745 \\
\hline KRF18 & $<\ldots$ & Reflective Ability & .724 \\
\hline KRF17 & $<. .$. & Reflective Ability & .774 \\
\hline KRF16 & $<$ & Reflectrve Abulity & .790 \\
\hline KEM25 & «... & Emotional Intelligence & .719 \\
\hline KEM24 & «... & Emotional Intelligence & .729 \\
\hline KEM23 & $<$ & Emotional Intelligence & .740 \\
\hline KEM22 & $<. .$. & Emotional Intelligence & .713 \\
\hline KEM21 & $<$ & Emotional Intelligence & .700 \\
\hline & & & \\
\hline
\end{tabular}

\begin{tabular}{|c|c|c|c|}
\hline & & & Estimate \\
\hline PKS35 & $<$ & Instructional Communication Pattern & .712 \\
\hline PKS34 & $<. .$. & Instructional Communication Pattem & .775 \\
\hline PKS33 & <... & Instructional Communication Pattem & .727 \\
\hline PKS32 & $<$ & Instructional Cónmunication Pattem & .778 \\
\hline PKS31 & $<$ & Instructional Communication Pattem & .735 \\
\hline PKS30 & $<$ & Instructional Communication Pattem & .719 \\
\hline PKS29 & $<\ldots$ & Instructional Communication Pattem & .750 \\
\hline PKS28 & $<\ldots$ & Instructional Communication Pattem & .741 \\
\hline PKS27 & $<$ & Instructional Communication Pattem & .707 \\
\hline PKS26 & $<$ & Instructional Communication Pattem & .777 \\
\hline KPD36 & $<$ & Pedagogic Competence & 820 \\
\hline KPD37 & $<$. & Pedagogic Competence & .766 \\
\hline KPD38 & $<.$. & Pedagogic Competence & 669 \\
\hline KPD39 & $<$ & Pedagogic Competence & .770 \\
\hline KPD40 & $<$ & Pedagogic Competence & .716 \\
\hline KPD41 & $<$ & Pedagogic Competence & .733 \\
\hline
\end{tabular}

The value of standardized regression in the table showed the loading factor of each indicator has values $>0.60$ which means that indicators were valid to measure the construction.

\subsection{Construct Reliability}

The construct reliability test was shown in the following table.

Table 2. Construct Reliability

\begin{tabular}{|l|l|l|}
\hline & Cronbachs:s Alpha & N of items \\
\hline Pedagogic Knowledge & .746 & 15 \\
\hline Reflective Ability & .865 & 5 \\
\hline Emotional Intelligence & .843 & 5 \\
\hline Instructional Communication Pattem & .924 & 10 \\
\hline Pedagogic Competence & .886 & 6 \\
\hline
\end{tabular}

The results showed that all instruments had very high reliability score (Cronbach's Alpha). It was supported by Nunnaly (1967) and Hinkle (2004) that in social research, Cronbach's Alpha $(\alpha)$ was above 0.60 indicating that the construct or variable was reliable. 


\subsection{Goodness of Fit Test}

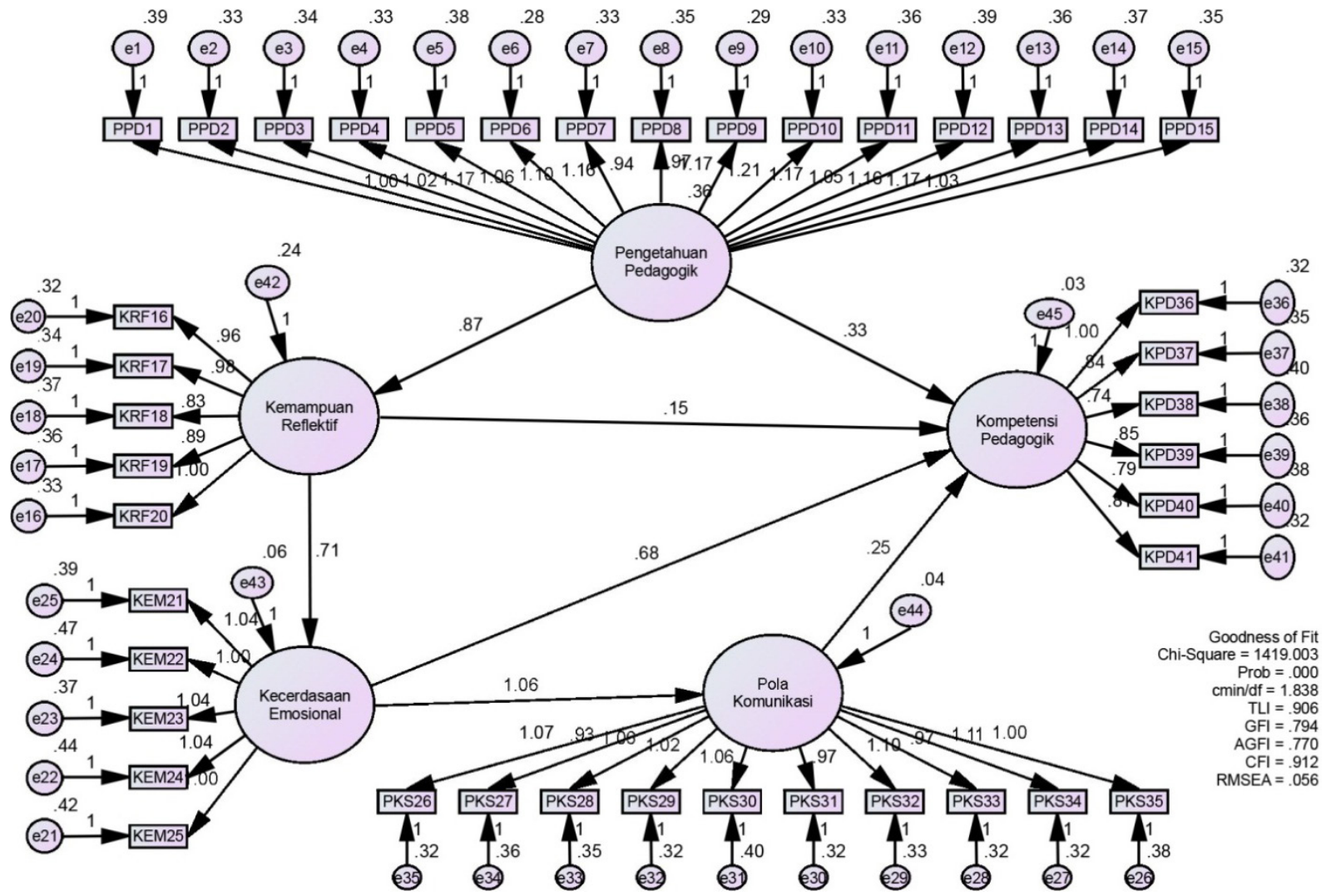

Figure 2. Goodness of Fit (GOF) Model

Table 3. Goodness-of-Fit Test Model

\begin{tabular}{|l|c|c|c|}
\hline Goodness-Of-Fit (GOF) & Analysis Result & Cut Off Value & Model Evaluation \\
\hline Chi-square & $\begin{array}{c}\chi^{2}=1130,83 \\
\mathrm{P}=0.000\end{array}$ & Probabilitas $\geq 0,05$ & Not Good \\
\hline TLI & 0.944 & TLI $>0.90$ & Good \\
\hline GFI & 0.833 & GFI $>0.90$ & Not Good \\
\hline AGFI & 0.814 & AGFI $>0.90$ & Not Good \\
\hline CFI & 0.948 & CFI $>0.90$ & Good \\
\hline RMSEA & 0.042 & RMSEA $\leq 0.08$ & Good \\
\hline
\end{tabular}

The diagram provided the detailed summary of the GOF (Goodness of Fit) test results on the research model. The further detailed data also was presented in table 3 .

The table showed that (1) Chi-square criteria $1130.83>$ 0.05 showed the bad result because the smaller score, the better result, (2) Goodness-of-fit test with TIJ $0.944>0.90$ showed good results, (3) GFI $0.833<0.90$ nearly reached 0.90 showed less good result but was still acceptable as a relatively good model, (4) AGFI 0.814 showed results that almost reached 0.90 so the model could still be received as a relatively good model, (5) CFI $0.945>0.90$ showed good results, (6) The RMSEA analysis as an index to compensate for the Chi Square statistics showed $0.042 \leq$ 0.08 represent acceptable. To conclude, GOF test met the criteria showing the model was fit to the data.

\subsection{Hypothesis Test}

The hypothesis test conducted using Critical Ratio (CR) criterion $>1.96$ or the value of Probability $(\mathrm{P})<0.05$ which meant: If the value of the probability (sig value) is $>0.05$ or-t table $<$ calculated $\mathrm{t}$ value $<\mathrm{t}$ table then the $\mathrm{H} 0$ was not rejected. If the value of the probability (sig value) is $<0.05$ or $\mathrm{T}$ count the $<-\mathrm{T}$ table or calculated $\mathrm{t}$ value $>\mathrm{T}$ table then $\mathrm{H} 0$ was rejected. 
Table 4. Goodness-of-Fit Model

\begin{tabular}{|c|c|c|c|c|c|}
\hline & & $\begin{array}{r}\text { Esti } \\
\text { mate }\end{array}$ & S.E. & C.R. & P Label \\
\hline Reflective Ability & <.. Pedagogic Knowledge & .805 & .090 & 8.980 & $8 * 8$ \\
\hline Emotional Intelligence & <... Reflective Ability & .636 & .068 & 9.331 & $* * *$ \\
\hline $\begin{array}{l}\text { Instructional } \\
\text { communication pattem }\end{array}$ & <... Emotional Intelligence & .382 & .074 & 5.195 & *** \\
\hline Pedagogic competence & 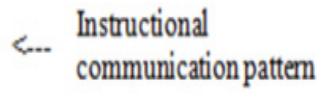 & .338 & .045 & 7.579 & *: \\
\hline Pedagogic competence & <... Emotional Intelligence & .467 & .072 & 6.474 & *** \\
\hline Pedagogic competence & <... Reflective Ability & .412 & .069 & 5.968 & $* * *$ \\
\hline Pedagogic competence & «... Pedagogic Knowledge & .399 & .060 & 6.690 & *** \\
\hline
\end{tabular}

From the table, the conclusion was as follows:

1. The value of the variable $\mathrm{c}$ pedagogical knowledge $=$ $* * *<0.05$ which meant $\mathrm{H} 0$ was rejected and H1was accepted, indicating the pedagogic knowledge variable affected positively and significantly to the reflective ability variable.

2. The value of the variable $\mathrm{p}$ reflective ability $=* * *$ $<0.05$ which meant $\mathrm{H} 0$ was rejected and $\mathrm{H} 1$ was accepted, indicating reflective capability variable had positive and significant effect on emotional intelligence variables.

3. The value of the variable $\mathrm{p}$ emotional Intelligence $=$ $* * *<0.05$ which meant $\mathrm{H} 0$ was rejected and $\mathrm{H} 1$ was accepted, indicating variable emotional intelligence positively and significantly affected the variable of instructional communication patterns.

4. The value $p$ variable of instructional communication pattern $=* * *<0.05$ which meant $\mathrm{H} 0$ was rejected and $\mathrm{H} 1$ was accepted, indicating the pedagogic competency variable affected positively and significantly to the pedagogical competence variable.

5. The value of the variable $\mathrm{p}$ emotional intelligence $=$ $* * *<0.05$ which meant $\mathrm{H} 0$ was rejected and $\mathrm{H} 1$ was accepted, indicating the variable of emotional intelligence is positively and significantly affected by the variable of pedagogical competence.

6. The value of variable $\mathrm{p}$ reflective ability $=* * *<$ 0.05 which meant $\mathrm{H} 0$ was rejected and $\mathrm{H} 1$ was accepted, indicating the reflective capability variable had positive and significant effect on the pedagogical competence variable.

7. The value of the variable $p$ pedagogical knowledge $=$ $* * *<0.05$ which meant $\mathrm{H} 0$ was rejected and $\mathrm{H} 1$ was accepted, indicating the pedagogical knowledge variable was positive and significant to the variable of pedagogical competence.

The structural equation was as follows

- $\quad$ Reflective ability $=0.805^{*}$ pedagogical knowledge + E
- $\quad$ Emotional intelligence $=0.636 *$ reflective ability + $\mathrm{E}$

- Instructional communication pattern $=0,382 * *$ emotional intelligence $+\mathrm{E}$

- $\quad$ Pedagogical competence $=0,338 *$ instructional communication pattern $+\mathrm{E}$

- Pedagogical competence $=0,467 *$ emotional intelligence $+\mathrm{E}$

- $\quad$ Pedagogical competence $=0,412 *$ reflective ability $+\mathrm{E}$

- Pedagogical competence $=0,399 *$ pedagogical knowledge $+\mathrm{E}$

- Pedagogical competence $=0.399 *$ pedagogical knowledge $+0.412 *$ reflective ability $+0467 *$ emotional intelligence $+0.338 *$ instructional communication pattern $+\mathrm{E}$

From forty-one indicators of five variables which met significance due to the loading factor of $>0.05$ could be described the indicator of the dominant variable as follows:

1. The pedagogical knowledge variable, which had 15 indicators, had dominant indicator namely PPD6 with the loading factor 0.803 . The lowest loading factor was PPD1 of 0.693 and 13 other indicators were at $>$ 0.700

2. The reflective ability variable, which had 5 indicators had similar dominant indicator which the loading factor $>0.700$.

3. The emotional intelligence variable which had 5 indicators had similar dominant indicator which loading factor $\geq 0.700$.

4. The instructional communication pattern variables which had 10 indicators had similar dominant indicator which the loading factor $\geq 0.700$

5. The pedagogical competence variable which had 6 indicators, had dominant indicator namely KPD36 with the loading factor 0.820 . The lowest loading factor was KPD38 was 0.669 and 4 other indicators were at loading factor $>0.700$

Based on the data explained, the development model of pedagogical competence could be seen in figure 3 . 

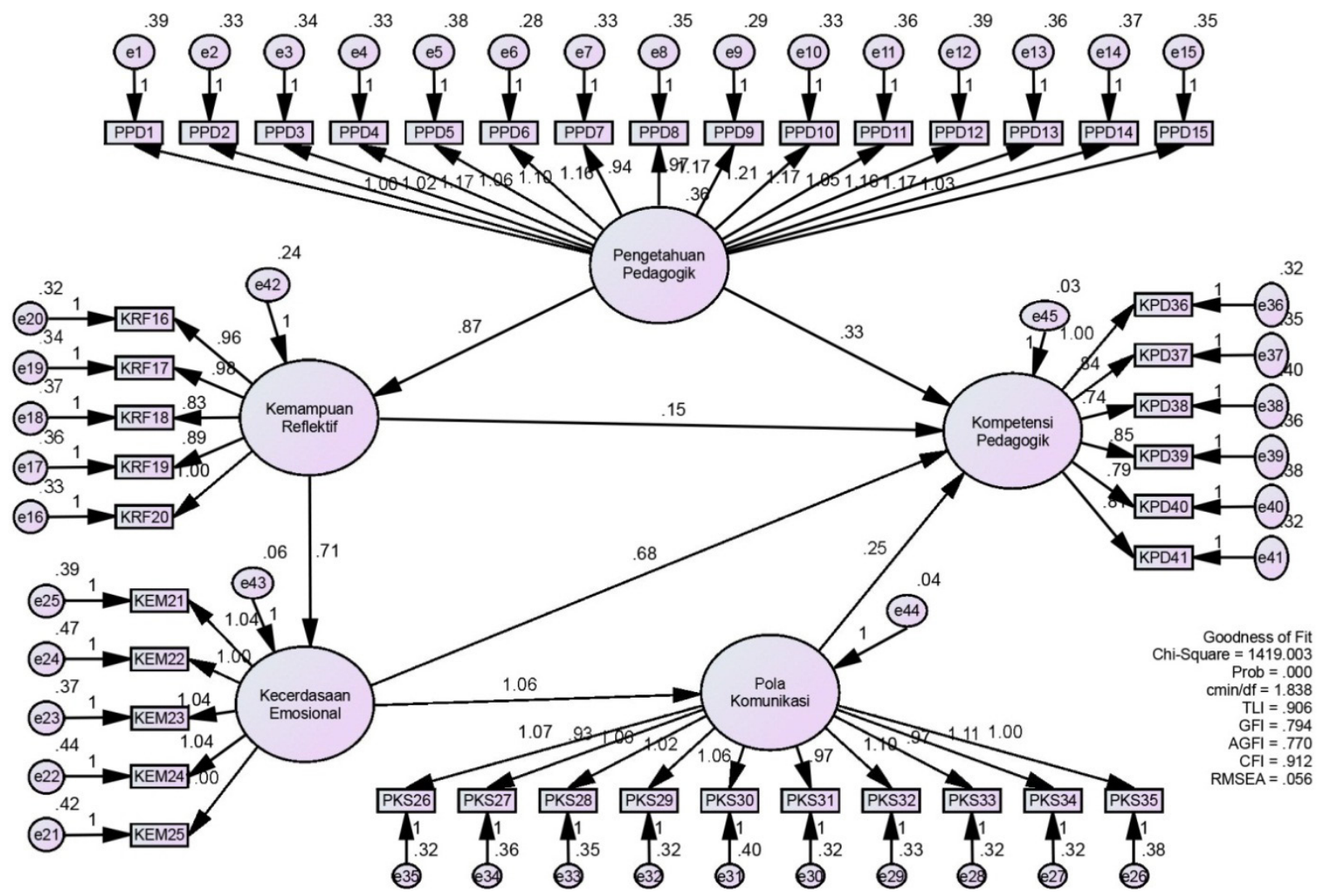

Figure 3. Pedagogical Competence Models for Elementary School Teachers

\section{Conclusions}

The development model of pedagogical competence can be undertaken by developing the variable of pedagogical knowledge, reflective ability, emotional intelligence, and instructional communication pattern. Development is conducted partially or simultaneously as each variable and indicator has influence to increase pedagogical competence with the implication as follows:

1. The higher the pedagogical knowledge, the higher the reflective ability so the reflective ability can be increased by gaining the pedagogical knowledge.

2. The higher the pedagogical knowledge, the higher pedagogical competence which pedagogical competence can be gained by increasing pedagogical knowledge.

3. The higher the reflective ability, the higher the emotional intelligence so the emotional intelligence can be increased by gaining the reflective ability.

4. The higher the reflective ability, the higher the pedagogical competence. Thus, to increase pedagogical competence can be done by gaining the reflective ability.

5. The higher the emotional intelligence, the more effective the instructional communication pattern will be. To increase the emotional intelligence is entailed the enhancement of effective instructional communication pattern
6. The higher the emotional intelligence, the higher the pedagogical competence. Therefore, to improve the pedagogical competence can be undertaken by enhancing the emotional intelligence.

7. The more effective the instructional communication pattern, the higher the pedagogical competence will be. So, it requires to increase pedagogical by conducting the effective instructional communication pattern.

8. The higher the pedagogical knowledge, the reflective ability, emotional intelligence and effective simultaneous instructional communication pattern, the higher the pedagogical competence will be. Thus, the enhancement of pedagogical competence can be carried out simultaneously by increasing the pedagogical knowledge, reflective ability, emotional intelligence and the effective instructional communication pattern.

\section{Acknowledgements}

This study was funded by a Research Grant of Ministry of Research and Technology and Higher Education, Republic of Indonesia (KEMENRISTEKDIKTI) 


\section{REFERENCES}

[1] Dotger BH. Core pedagogy: Individual uncertainty, shared practice, formative ethos. J Teach Educ. 2015; 66 (3): 21526.

[2] Berchini CN. Critiquing un/critical pedagogies to move toward a pedagogy of responsibility in teacher education. $\mathrm{J}$ Teach Educ. 2017.

[3] Faltis, Christian \& Abdei J. Extraordinary pedagogies for working within school setting serving nondominant students. Vol. 37. USA: Sage Publication;2015. 38-40 p.

[4] Aprianto J. Pengaruh kompetensi pedagogik guru terhadap prestasi siswa dalam mata pelajaran IPS terpadu di SMP Negeri 9 Benai Kabupaten Kuantan Singingi. Universitas Islam Negeri Sultan Syarif Kasim Riau; 2011.

[5] Sulaiman, Yuliansari I. Hubungan kompetensi pedagogik guru dengan kinerja guru SDN di kecamatan Banjarmasin Utara. Paradigma. 2015;10(1).

[6] Zygmunt E, Cipollone K, Tancock S, Clausen J, Clark P, Mucherah W. Loving out loud: Community mentors, teacher candidates, and transformational learning through a pedagogy of care and connection. $J$ Teach Educ. 2018;69(2):127-39.

[7] Kirchgasler C. True grit? Making a scientific object and pedagogical tool. Am Educ Res J. 2018;283121775224.

[8] Carter Andrews DJ, Richmond G, Floden R. Teacher education for critical democracy: Understanding our commitments as design challenges and opportunities. Journal of Teacher Education. 2018;69(2):114-7.

[9] Khalik MG. Guru dan Permasalahannya. Kompasiana. 2016;

[10] Budhayanti CIS. Gambaran kompetensi guru kelas SD di Jakarta dan Tangerang. J Perkota. 2012;4(1):1-27.

[11] ndriani F. Kompetensi pedagogik guru dalam mengelola pembelajaran IPA di SD dan MI. Fenomena. 2015;7(1):17-28

[12] Zulfadewina, Nurmawati SFM. Peningkatan Profesionalisme Pedagogik Mengajar Guru TK, SD, SMP/Mts melalui Pelatihan Mengajar Gaya Motivator (MGM) se Cabang Aisyiyah Ciracas, Jakarta Timur. SOLMA. 2018; 7(1): 83-9.

[13] Slameto S. Permasalahan Terkait Profesi Guru SD. Scholaria. 2014;4(3):1-12.

[14] Zulfadewina, Nurmawati, Meilana SF. Peningkatan profesionalisme pedagogik mengajar guru TK, SD , SMP/ MTS melalui pelatihan Mengajar Gaya Motivator (MGM). Solma. 2018; 7(1): 83-9.

[15] Liputan6.com. Kekerasan Pada Anak, Dipukuli hingga Diracuni. Republika Online. 2018.

[16] ICRW. Survei ICRW: $84 \%$ anak Indonesia mengalami kekerasan di sekolah. Liputan 6.com. 2015.

[17] KPAI. Kekerasan Anak Hari Ini. Kompas. 2018.

[18] Retno Listyarti. Kekerasan pada Anak di Sekolah Kian Sadis. Kompas. 2017.
[19] Karthwohl DR, Benjamin SB, Bertram BM. Taxonomy of educational objectives. Longman.

[20] A.M S. Interaksi dan Motivasi Belajar Mengajar. Jakarta: Rajagrafindo Persada (Rajawali Pers); 2004. 200-210 p.

[21] Paulus Wahana. Mengenal Pendekatan Paradigma Pedagogik Reflektif dalam Pendidikan untuk Membangun Manusia yang Cerdas dan Humanis. Didaktika. 2010;1(1).

[22] Elizabeth Graham. What Patterns of Teacher- Student Verbal Communication Exist in My Classroom? dlib.indiana.edu. 2016; 1(1).

[23] Daniel Goleman. Emotional Intelligence, Kecerdasan Emosional Mengapa Lebih Penting daripada IQ? Jakarta: PT. Gramedia Pustaka Utama; 2007.

[24] Kinicki A, Mel F. Organizational behaviour: A practical, problem-solving approach. New York: McGraw-Hill Education; 2015 .

[25] M Pawit Yusuf. Komunikasi Instruksional, Teori dan Praktek. Jakarta: Bumi Aksara; 2010.

[26] Staton AQ- S. A Framework for Instructional Communication Theory: The Relationship Between Teacher Communication Concerns and Classroom Behavior. Commun Educ J. 2009;30(4):354-66.

[27] Riyana C. Peningkatan Kompetensi Pedagogis Guru melalui Penerapan Model Education Centre of Teacher Interactive Virtual (Educative). 2010; 11 (1): 50-65. Avail able from: www.jurnal.upi.edu/file/Cepi_Riyana-6.pdf

[28] Jaafar NAM, Fariza Khalid. Keberkesanan kemahiran komunikasi di kalangan guru dalam penggunaan persekitaran pembelajaran maya (Frog VLE). Akad Edu [Internet]. 2014; 4 (22): 44-56. Available from: www.acad emia.edu/10368490/Keberkesanan_Kemahiran_Komunika si_Di_Kalangan_Guru.

[29] Nor Azlah Mohd Jaafar, Fariza Khalid. Keberkesanan kemahiran komunikasi di kalangan guru dalam penggunaan persekitaran pembelajaran maya (Frog VLE). Pengajaran Sumber Dan Teknol Mklm. 2014; 63-9.

[30] Yakub S, Gunawan R, Halim J. Pengaruh kemampuan komunikasi dan kecerdasan emosional terhadap kinerja karyawan pada PT. Perkebunan Nusantara I (Persero) Aceh. J Ilm SAINTIKOM. 2015; 14(3): 160-70.

[31] McCroskey JC, Valencic KM, Richmond VP. Toward a general model of instructional communication. Commun Q. 2004; 52(3): 197-210.

[32] Basset, Ronald E. dan MJS. The Definition of Education Technology, AECT. [Internet]. Depdikbud, Dirjen Dikti, NKK. Jakarta; 1981. Available from:http:///www.anekama kalah.com > Home > Pendidikan.

[33] Susanto AS. Filsafat komunikasi. Bandung: Bina Cipta; 2006.

[34] D. ANR, Kartika T, Gautama MI. Menemukan pola komunikasi pada metode mengajar para pengajar muda pada program Indonesia mengajar. In: Seminar Nasional FISIP Unila. Unila; 2017.

[35] Ball DL, Thames MH, Phelps G. Content knowledge for teachsing: Whati makes it special? J Teach Educ. 
2005;59(5):389-407.

[36] Prayitno. Faktor-faktor penyebab tindakan kekerasan. Digilib Unlla [Internet]. 9AD; Available from: digilib.unil a.ac.id/.../S KRIPSI TANPA BAB PEMBAHA..\%0A\%0A.

[37] Rifma. Optimalisasi pembinaan kompetensi pedagogik guru [Internet]. Jakarta: Penerbit Kencana; 2016. Available from: digilib.unila.ac.id/.../S KRIPSI TANPA BAB PEMBAHA..\%0A\%0A.

[38] Zeichner K, Payne KA, Brayko K. Democratizing Teacher Education. J Teach Educ. 2015;66(2):122-35. 